\title{
REFLECTION
}

\section{The Dream of Home Ownership}

David Loxterkamp, MD

Seaport Family Practice, Belfast, Maine
Conflicts of interest: none reported.

\section{CORRESPONDING AUTHOR}

David Loxterkamp, MD Seaport Family Practice 41 Wight St Belfast, ME 04915 dr.loxterkamp@myfairpoint.net

\begin{abstract}
Part of the American Dream involves home ownership and its claim to a stronger investment in one's family, neighborhood, and community. The medical version of that dream is called private practice. Almost overnight, it seems, we have awakened to the reality that most primary care physicians are now employed by large corporations or hospital networks. What does this mean for our patients and the practice of medicine? Did patients lose a sense of ownership when insurance companies began to speak on their behalf? Have boutique practices, Internet sales, and online information banks restored their control? This essay explores the fundamental question, "Does ownership matter?" and suggests what we all can do to retrieve paradise lost.
\end{abstract}

Ann Fam Med 2009;7:264-266. DOI: 10.1370/afm.978.

"Business!" cried the ghost, wringing its bands again. "Mankind was my business."

\section{Charles Dickens ${ }^{1}$}

W ith all the fuss about the patient-centered medical home, little has been said about who will own it. Do we know? Does it matter?

We don't know, as it turns out. The most recent data set is from 2001, when the American Medical Association, the Center for Studying Health System Change, and the Census Bureau reported a range in the number of independent physicians from between $61.5 \%$ to $29.3 \%{ }^{2(p 655-657)}$ The authors of a recent editorial in the New England Journal of Medicine concluded that "the percentage of US physicians who own their own practice has been declining at an annual rate of approximately $2 \%$ for at least the past 25 years," $2(\mathrm{p} 655)$ but the rate of decay is not linear. It is more reasonable to guess that we are at the inflection point in a hyperbolic rate of change, and that parts of the country have moved well beyond it.

Anecdotally, I have seen a seismic change in practice ownership during the 2 decades since I moved to Maine. In the summer of 1984, no primary care physicians were employed by our local hospital. In the past 5 years, physicians who left or retired were all self-employed ${ }_{i}$ contracted physicians took their place. The medical staff is now mostly on hospital payroll.

This trend is neither isolated nor inexplicable. Graduates of private medical schools carry a median debt of $\$ 180,000$; the burden of public school graduates is only slightly smaller at $\$ 145,000.00 .^{3}$ Large corporate and hospital-owned systems are poised to invest heavily in recruitment incentives, loan forgiveness programs, higher salaries, and freedom from administrative worry. But at what cost for primary care?

Ownership changes human behavior. Research shows that homeowners are more satisfied, civic-minded, and politically active than those who rent. ${ }^{4,5}$ Their children do better in school, have fewer behavioral problems, and are less likely to become pregnant as teenagers. The differences, though not easily explained, are real, consistent, and lasting. Ownership serves as an anchor for an otherwise fluid society $y_{i}$ money is the tangible and symbolic measure of that investment. Ownership encourages stability, upon which the doctor- 
patient relationship is moored. And relationships-those great laboratories of the self-are where we might finally face our social fears instead of endlessly searching for a better fit, moves some have called the geographic cure.

\section{IT'S A WONDERFUL LIFE}

Americans have long dreamed of home ownership. The rate rose from $29 \%$ of households in 1900 to $68.8 \%$ today. ${ }^{6}$ Major growth began in the 1940 s, when government codified tax incentives and footed the bill of social infrastructure. It was about this time that Frank Capra directed his favorite film, It's a Wonderful Life, starring James Stewart (George Bailey), Donna Reed (his wife, Mary), and Lionel Barrymore as the real estate tycoon, Henry Potter. Upon release, the film was a box office flop, but it became a Christmas classic in the 1970s after copyright protection lapsed and television stations rebroadcast it each season.

It's a Wonderful Life is the story of a small-town savings and loan manager who comes to regard his worth through the lives he has touched-family, friends, and loan recipients. George Bailey inherited the dream of home ownership from his father, Peter, who once said, "It's deep in the race for a man to want his own roof, walls, and fireplace." Potter knew that there was profit and power in keeping the "discontented, lazy rabble" of Bedford Falls in rental units owned by him. As a board member of the Bailey Brothers Building and Loan Company, he demanded to know, "Are you running a business or a charity ward?" George countered with his famous defense:

Just remember this, Mr. Potter, that this rabble you're talking about [does] most of the working and paying and living and dying in this community. Well, is it too much to have them work and pay and live and die in a couple of decent rooms and a bath? Anyway, my father didn't think so. People were human beings to him, but to you...they're cattle. Well, in my book, he died a much richer man than you'll ever be. ${ }^{7}$

A major study of the patient-centered medical home, The National Demonstration Project, was concluded in June of 2008. It is curious that 23 of the 36 selected practices, or $63.8 \%$, were physician-owned, a figure strikingly similar to the national home ownership average. The perception that family doctors still own their practices, or want to, is at odds with the current trend for residency graduates to take salaried positions in hospital systems.

\section{RIGHTS OF OWNERSHIP}

What will be the consequence? The culture of group practice was studied in 2003 by Curoe, Kralewski, and
Kassi. ${ }^{8}$ They found that 2 factors - size and ownership_-were pivotal. The authors surveyed 547 primary care clinicians from 148 Midwestern clinics and analyzed their data using contingency and complexity theory. They found that clinics owned by private or hospital-based systems had "less organizational trust, less identification with the group practice, and less collegiality among physicians." They also found that "quality emphasis increases as ownership shifts to systems and their larger organizational capacity."

In my own practice, I wonder what would be different if our business plan required the approval of a corporate board or CEO. Would we have become a Rural Health Center, which has allowed us to carry a generous caseload of Medicare/Medicaid patients? Would we prescribe Suboxone in our office in response to the epidemic of opioid abuse in rural Maine? Would we allow, let alone encourage, clinicians to work on a part-time basis or take sabbatical leave, as I did to hone my skills for treating patients infected with HIV when they began to return home with end-stage disease? Would we know or care what our patients earn and can afford? We would still be practicing here, seeing generations of patients for more than a generation of time? Would we have thought to improve our practice enough to apply for or have been chosen for the National Demonstration Project? Is it possible that it chose so many physician-owned practices because we were the ones willing to change?

My point is this: ownership influences the choices we make. And by ownership, I mean more than who signs our paycheck. It is a reflection of our values and integrity; it reveals who we are and what matters in our lives. A dozen years ago I wrote about the many voices that clamor for the doctor's attention. ${ }^{9}$ We are obliged to listen to licensing boards, credentialing committees, peer-review organizations, and insurance carriers. We respond to the legacy of general practitioners who laid the moral foundation for family medicine, the humanists who reformed it, and consultants who now sell it with direct-to-consumer marketing. Add the bankers who hold our student loans, and, equally, the graduates who understandably rush to jobs that offer the best return on their career investment. The new hospital bosses have their own bills to pay, including for large surgical suites, cardiac catheterization laboratories, dialysis units, and imaging departments. Some of us, too, are haunted by whispers of self-doubt, the call of duty, or the siren song of pride. But this chorus carries a partial tune. The missing voice, the most insistent and challenging one, the person who will deliver us to our finest hour, who will talk us through every moral conundrum, is the patient who we thought needed us. 


\section{VOX CLAMANTIS IN DESERTO}

In the 1960s, family practice took advantage of, but certainly did not create, the social forces that shaped our emerging specialty. So today, we cannot expect it to counter the sea change in American culture. It is certainly possible that family medicine will go the way of the family market and family farm. Even then, we can take ownership in our practices. We can be the owners and leaders of an American-styled primary care delivery system. Hospital managers will always attend to the bottom line and move to maximize their profits. Profit lies in technology, procedures, tests, and drugs. There is no real incentive to foster the kind of lifestyle changes, preventative strategies, and strong relationships that makes crisis care a matter of last resort.

I also doubt that the current fashion of boutique, subscription, or Ideal Micro Practices that accept (only) direct payment from their clientele will secure the goal of a more responsible and responsive health care system. Too many patients lack the money, intelligence, and maturity to take care of themselves. And although the structural arrangement of receiving payment directly from the patient helps to reinforce the locus of responsibility, it is not necessary or sufficient to sustain ongoing relationships.

Those of us who sit each day with the dying, bereft, lonely, and disillusioned, those who suffer chronic pain or struggle to buy their medications, know clearly what George Bailey learned from his fateful jump: "Strange, isn't it? Each man's life touches so many other lives, and when he isn't around he leaves an awful hole, doesn't he?" I hope we will not let primary care become an awful hole. Will we be the voice that speaks for the lives we touch and touch us in return?

Together we can advocate for reimbursement and loan forgiveness programs, admissions policies, and training sites that favor primary care. Together we must demand a broader, more-farsighted, and compassionate view of the business of medicine. I am reminded here of another Christmas classic, and words uttered equally to the point:
"Business!" cried the ghost, wringing its hands again. "Mankind was my business. The common welfare was my business; charity, mercy, forbearance, and benevolence, were, all, my business. The dealings of my trade were but a drop of water in the comprehensive ocean of my business."1

As we indenture our labor, mortgage our homes, lease our cars, and live on borrowed time, let's at least own our conscience and the decisions about whom we serve. And work to create systems and structures that dignify and promote human relationships-the very foundation of primary care. We cannot afford to relinquish the dream. Ownership, by which I also mean a sense of commitment and empowerment, begins at home, in the medical home, at the heart of medicine.

To read or post commentaries in response to this article, see it online at http://www.annfammed.org/cgi/content/full/7/3/264.

Key words: Family practice; social responsibility; physician's practice patterns; physician-patient relations; medical practice management

Submitted June 11, 2008; submitted, revised, September 5, 2008; accepted September 29, 2008.

\section{References}

1. Dickens, C. A Christmas Carol. Boston, MA: The Atlantic Monthly Press; 1920:33.

2. Isaacs SL, Jellinek PS, Ray WL. The independent physician-going, going.... N Engl J Med. 2009;360(7)655-657.

3. Baldauf S. Medicine: seeing the big picture. US News \& World Report. 30 March 2007.

4. Kerch S. The happy homeowner. It's academic: home ownership breeds satisfaction. CBS.MarketWatch.com. 26 June 2003. http:// www.marketwatch.com/news/story/social-benefits-homeownership/ story. aspx?guid $=\{2 F 344 F 23-B D E 9-4 C A 9-91 D 2-2 A 8 D F 6051194\}$.

5. Rossi P, Weber E. The Social Benefits of Homeownership: Empirical Evidence from National Surveys. Housing Policy Debate. Vol 7, Iss 1. Fannie Mae Foundation; 1996.

6. Yglesias, M. Why home ownership? TheAtlantic.com. 2 Sep 2007. http://matthewyglesias.theatlantic.com/archives/2007/09/why_homeownership.php.

7. Dirks T. It's a Wonderful Life [review]. www.filmsite.org/itsa.html.

8. Curoe A, Kralewski J, Kaissi A. Assessing the cultures of medical group practice. J Am Board Fam Pract. 2003;16(5):394-398.

9. Loxterkamp D. Hearing voices: how should doctors respond to their calling? New Engl J Med. 1996;335(26):1991-1993. 